\title{
Miscellany
}

\section{Crisis intervention}

The National Institute of Crisis Intervention Therapy and Research was set up by Huddersfield Health Authority during early 1988 to organise educational programmes in social and community aspects of mental health and mental handicap. It was also intended that the Institute would become a focal point for those interested in the field and to disseminate information about recent developments in crisis intervention. Dr N. Rao Punukollu is the Institute Director and he is also the Clinical Leader of a crisis intervention team based in a sectorised area of Huddersfield. Further information: The Director, National Institute of Crisis Intervention Therapy \& Research, 63 Nabcroft Lane, Crosland Moor, Huddersfield HD4 5DU (telephone 0484658054, Mrs A. Welburn, or 0484654711 , extension 3588, Mrs C. Bailey; fax: $0484654777)$.

\section{New publications}

Residential Needs for Severely Disabled Psychiatric Patients: The Case for Hospital Hostels, edited by Kate Wooff, summarises the experience of hospital hostel provision and follows on the series of Department of Health seminars on the same topic. It costs $£ 7.50$ and is available from the Mental Health Information Unit, Pendleton House, Broughton Road, Salford M6 6LQ (telephone 061736 2673).

Age Concern Scotland has recently published Dementia Forums - An Outline of Some Developments in Fife by Joyce Cormie which describes how the Social Work Departmant, Health Board and the voluntary sector come together to deliver speedy and effective help and support to dementia sufferers and their carers in the community. It is available from Age Concern Scotland, 54A Fountainbridge, Edinburgh EH3 9PT and costs $£ 2$, including postage.

Better Lives: A Review of the Quality of Life of People Living at Borcourt Hospital and Proposals for Change is the report of the National Development Team, a government sponsored advisory body. It costs $£ 2.50$ and is available from PO Box 21, Stanmore, Middlesex HA7 1AY. (Please make cheques payable to the Department of Social Security.) Further information about the team's work and its reports on visits elsewhere is available from the NDT Secretariat, Room C411, Alexander Fleming House, London SE1 6BY (telephone 071403 7991).

\section{Forthcoming events}

The next Conference of the Association for Psychoanalytic Psychotherapy in the British Health Service (APP), entitled 'Preserving the Future', will be held from 8-10 February 1991 at Regent's College, Regent's Park, London. Themes include: A European Federation of Psychoanalytic Psychotherapy and Should Psychoanalytic Psychotherapists be only Doctors or Psychologists? Conference fee: $£ 125$ (£140 after 15 January) Further information and application forms: APP European Conference, c/o Mrs June Ansell, 87 St Mary's Mansions; St Mary's Terrace, London W2 1SY.

The National Schizophrenia Fellowship will be holding a National Training Conference on 24
October 1990 at Westminster Central Hall, Storey's Gate, London SW1 entitled Infuencing Training in Mental Health: The Relatives' and Sufierers' Contribution. Fee (to include coffee, lunch and tea) $£ 70$ per person (voluntary organisations $£ 35$ ). Further information and application forms: Helena Bakewell, NSF, 28 Castle Street, Kingston, Surrey KT1 1SS (telephone 081547 3937; fax: 081547 3862). Closing date: 17 October 1990.

A conference entitled Recent Developments in Child and Adolescent Psychiatry will be held at the Institute of Psychiatry on 6 and 7 December 1990 . Course fee: $£ 150$ (including lunch and refreshments). Further information: Mrs Lee Wilding, Conference Office, 
Institute of Psychiatry, De Crespigny Park, London SE5 8AF (telephone 0717035411 , extension 3170).

The Forensic Psychiatry Specialist Section Annual Residential Conference will be held on 22 and 23 February 1991 at the Viking Hotel, York.

The Second National Senior Registrars' Residential Conference will be held on 19-21 April 1991 at the Manchester Business School.

A one-day conference entitled Manic Depression: The Implications for Community Care will be held on 19 October 1990 at Westminster Cathederal Conference Centre, Victoria, London SW1. Programme and booking form: Manic Depression Fellowship, 13 Rosslyn Road, Twickenham, Middlesex TW1 2AR.

A conference entitled Breaking Bad News will be held on 8 October 1990 in the Clarendon Wing of The General Infirmary at Leeds. Registration fee: $£ 40$ (includes coffee, lunch and tea). Further information: Julia Dunning, Convenor and Organiser: PO Box 12, Whitley, Goole, North Humberside, DN14 0JT (telephone 0977 662560).

The Eighth Annual Meeting of the Society for Psychotherapy Research (UK): Papers are invited for this meeting, to be held at the Raven Hall Hotel, Ravenscar, North Yorkshire, 7-10 April 1991. Abstracts (500 words maximum) should be sent to Dr Else Guthrie, Department of Psychotherapy, Gaskell House, Swinton Grove, Manchester M130EU. Deadline for submissions: 4 November 1990.

The Second Mind and Brain Symposium will be held on 20 October 1990 at the Institute of Psychiatry, Wolfson Lecture Theatre. Fee: $£ 40$ (to include lunch and refreshments). Registration by cheque made payable to Dr Peter Fenwick at the Institute of Psychiatry, De Crespigny Park, Denmark Hill, London SE5 8AF (telephone 0717035411 , extension 3278).

The first Management and Planning Course of the National Training Scheme for Senior Registrars/ Consultants in Mental Handicap will take place from 7-9 December 1990 at the Huddersfield Royal Infirmary Postgraduate Centre. This course is specifically designed for the clinicians working in Mental Handicap services to deal with day to day practical management and planning issues. Course fee: £185.00. Further details: Dr N. Rao Punukollu, Course Organiser, Department of Psychiatry, St Luke's Hospital, Crosland Moor, Huddersfield HD4 5RQ (telephone: 0484 654711, extension 3588).

Applications for the Diploma/MSc in General Psychiatry, Department of Psychiatry, University of
Keele, are being considered. The Diploma and MSc are taught courses, with formal examinations, audited cases and a dissertation. Teaching is modular and can be attended on a half day or one whole day per week within university terms. Further information: The Course Tutor, Diploma and MSc in General Psychiatry, Department of Psychiatry, North Staffs Hospital Centre, Thornburrow Drive, Hartshill, Stoke on Trent ST47QB (telephone 0782 49144, extension 4047).

The next Management Course for Senior Registrars in Psychiatry at the University of Keele, directed by Professor Roger Dyson, will be held from mid-day on 16 January to mid-day on 18 January 1991. Further details: Tanya Matthews, Suite 2.1, Science Park, University of Keele, Keele, Staffordshire ST5 5SP (telephone 0782621111 , extension 3646).

Community Management of Mental Disorders: a comprehensive course for health and social service professionals engaged in the development of community-based services for the mentally disordered and their caregivers is announced. This will consist of five modular workshops on case management, drugs and diagnosis, family care, life skills training and home-based intensive care. Workshops are skillsbased, of 3-5 days duration, and begin in late September. Further information: Brenda Stroud, Buckingham Mental Health Service, 22 High Street, Buckingham MK18 1NU (telephone 0280817973 ).

The Second International Congress on Emergency Psychiatry will be held from 3-5 April 1991 at the RAI Congress Centre, Amsterdam. Proposals for papers or other presentations are welcomed. Further information: Leids Congress Bureau, PO Box 16065, 2301 Leiden, The Netherlands (telephone 0103171 275299; fax 0103171275264 ).

An international conference entitled Changing Mental Health Care in the Cities of Europe will be held from 10-13 April 1991 at the RAI Congress Centre, Amsterdam. Further information: Congress Secretariat, QLT/CONGREX, Keizersgracht 782, 1017 EC Amsterdam, The Netherlands (telephone 0103120 261372; fax:010 3120 259574).

The Association for Death Education and Counseling (ADEC) will be holding its 13th Annual Conference at the Duluth Entertainment Convention Center in Duluth, Minnesota from 26-28 April 1991. There is now a call for proposals (to be postmarked no later than 15 October 1990). Further information: Sally Featherstone (telephone 0101314362 1966). Association headquarters: Association for Death Education and Counseling, 638 Prospect Avenue, Hartford, CT 061054298, USA (telephone 0101203232 4825; fax 0101203232 0819). 
The second annual conference of the Southampton Psychiatric Rehabilitation Service entitled 'Looking for Quality in Psychiatric Rehabilitation' will be held on 2 October 1990 at Southampton General Hospital. It will be chaired by Dr Brenda Morris and speakers include Professor Kathleen Jones, Dr Geoff Shepherd and $\mathrm{Mr}$ Chris Heginbotham. Further details and application forms: Mrs Penny Bartlett, Department of Psychiatry, Royal South Hants Hospital, Graham Road, Southampton SO9 4PE (telephone 0703 634288, extension 2561).

A day symposium on Community Psychiatry: a special reference to General Practitioners will be held on 19 October 1990 at the Postgraduate Centre, City Hospital. Further information: Dr H. N. Ghadiali, Kingsway Hospital, Derby DE3 3LZ (telephone 0332362221 , extension 207).

Godden Green Clinic will be holding a second season of continuing medical education seminars entitled Management of Mental Illness within the Community. 11 September 1990 Computers in General Practice, Friend or Foe?; 9 October 1990 Monitoring of Psychiatric Patients in the Community following Mental Hospital Closures; 7 November 1990 Early Identif- cation of the Alcohol Patient in General Practice. Accreditation for Postgraduate Allowance has been applied for. Further information: Niall J. Hall, Hospital Director, Godden Green Clinic, Godden Green, Sevenoaks, Kent TN15 0JR.

The European College of Neuropsychopharmacology (ECNP) will be holding a Workshop on Receptors from 1-3 October 1990 and a Symposium entitled Recent Advances in the Treatment of CNS Disorders on 4 October at Loews Hotel, La Napoule, France. Further information: John Alexander, Synthélabo Recherche, 58 rue de la Glacière, 75013 Paris, France (telephone 01033143362222 , extension 1405; fax 01033143362177 or 43316217$)$.

Psychiatry and Clinical Psychology: How Many? How Managed? Joint Conference between the College and The British Psychological Society to be held on 11 October 1990 at The Society of Chemical Industry, 14/15 Belgrave Square, London SW1. Speakers will include Marc Binns, Dr David Pilgrim, Derek Mowbray, Dr Fiona Caldicott, Clive Skilbeck and Dr Doug Cameron. $\mathfrak{£ 4 5 . 0 0}$ for all categories of members of both bodies and $£ 70.00$ for nonmembers. Further information: Deborah Hart, The Royal College of Psychiatrists.

\section{GASKELL Royal College of Psychiatrists Lectures on the History of Psychiatry}

\section{The Squibb Series}

\section{Edited by R. M. Murray \& T. H. Turner}

"Thus in psychiatry he was entirely selftaught.... Alexander Walk, Chapter 2. Medico-psychologists, Maudsley and The Maudsley

"It was Jones who conceived the idea of the famous Komittee whose main function was to defend Freud from having to face any further public criticisms. They were to function secretly, and Freud presented each of the members with an antique Greok intaglio ... mounted in gold rings. Jones was the only member of the Komittee to lose his ring. "Thomas Gruffydd Davies, Chapter 4, 'Truth is a point of view': an account of the life of Dr Ernest Jones

"Insane ear seems to have been commonest in genoral paralytics, and its disappearance, from the literature at least, coincided with the decline of general paralysis. Yet general paralysis continued to bea common disorder for decades after insane ear had apparently gone." Edward Hare. Chapter 6, Old familiar faces: some aspects of the asylum era in Britain
£10, 236 pp, ISBN $090224132 X$

"This English disease, affecting, he insisted, as many as one-third of all people of quality in England, was the result of high living, prosperity, and progress unique on such a wide scale in early 18th-century England. Cheyne flattered his patients: only those of quick and lively dispositions and good breeding suffered from the nerves." William F. Bynum, Chapter 8. The nervous patient in 18th- and 19th-century Britain: the psychiatric origins of British neurology

"Abnormal childhood sexuality was an equally strong clue to the presence of "chronic sepsis and toxemia ... [and] in a number of cases the colon has been resected with improvement in the individual'." Androw Scull, Chapter 10. Desperate remedies: a Gothic tale of madness and modern medicine

"Claude Bernard ... opposed ... the view that averages or indeed statistics could ever lead to exact science." German Berrios, Chapter 12, Memory and the cognitive paradigm of dementia during the 19th century: a conceptual history 